\title{
THE POSSIBILITY OF USING THE KODÁLY METHOD TO TEACH MUSIC LITERACY IN THAILAND
}

\author{
Twatchai Narkwong $^{1}$
}

\begin{abstract}
The Kodály method of teaching music literacy was used by the writer to teach Western music notation to elementary students, at the laboratory school of Kasetsart University in Thailand for six years. The students achieved good competencies in reading music, singing and playing the recorder. The method was afterwards disseminated to music teachers of municipal schools in Bangkok and was accepted. It seems that the method will spread further to other groups of music teachers.
\end{abstract}

\section{Introduction: Music Education in Thailand}

Music is an important subject in the Thai education system. Along with subjects like physical education, arts, and ethics, music is considered valuable for the development of human behaviour. In elementary and junior high levels (prathom 1-6 and mathayom 1-3), music is compulsory, but in senior high level (mathayom 4-6) it is an elective. In kindergartens music is a core subject and plays a major role in

\footnotetext{
1 Department of Communication Arts, Faculty of Humanities, Kasetsart University
}

developing young personalities. In the Thai education system, the study of music is covered by three basic activities; singing, movement (with music), and playing musical instruments. These subjects can further be divided into: Thai music, Western music, and Thai traditional dance. Courses in Thai music and Thai traditional dance aim to provide students with capabilities to appreciate, to perform and to preserve their native arts. The study of Western music offers students the opportunity to know about classical music, jazz music, and music from other parts of the world. This follows the belief that an educated person should have knowledge about classical music (this belief may be similarly found in Japan, Korea, and China). For this reason, the Ministry of Education includes the reading and writing of Western music notation in the Thai school music curriculum. Music history, introduction of musical instruments, and band and orchestra are added to the music reading and writing courses.

\section{Introduction of the Kodály Method into Thailand}

Previous attempts have been made to find a suitable method to teach Western music notation in Thai schools. Private institutions are more successful than public schools in this respect. Children from rich families attend courses offered 
by these institutions such as in piano, electone, guitar, violin, ballet, and jazz dance. Famous teaching methods such as Yamaha's method of teaching piano (JMC, JXC) and Suzuki's method of teaching violin are applied in these institutions. In public schools, the Ministry of Education gives direction only regarding the content or "what to teach", but does not give advice on the method of "how to teach". This is left up to each individual teacher to choose his/her own way and good teachers are imitated by others.

The Kodály method was introduced to Thailand in 1977 by Mrs. Carolyn Kingshill, the former Head of the Music
Department of Payap University in Chiang Mai, in northern Thailand. However, the method was not dispersed to other schools. In my opinion, the Kodály method is appropriate for teaching music literacy in Thailand because students can learn to read and write music through singing, which is a popular pastime. Thailand is a developing country and Thai students cannot afford to buy rare and expensive musical instruments. Therefore, to learn music literacy through singing is the most inexpensive way to invest. Students require only their voices and perseverance to get sufficient basic music knowledge.

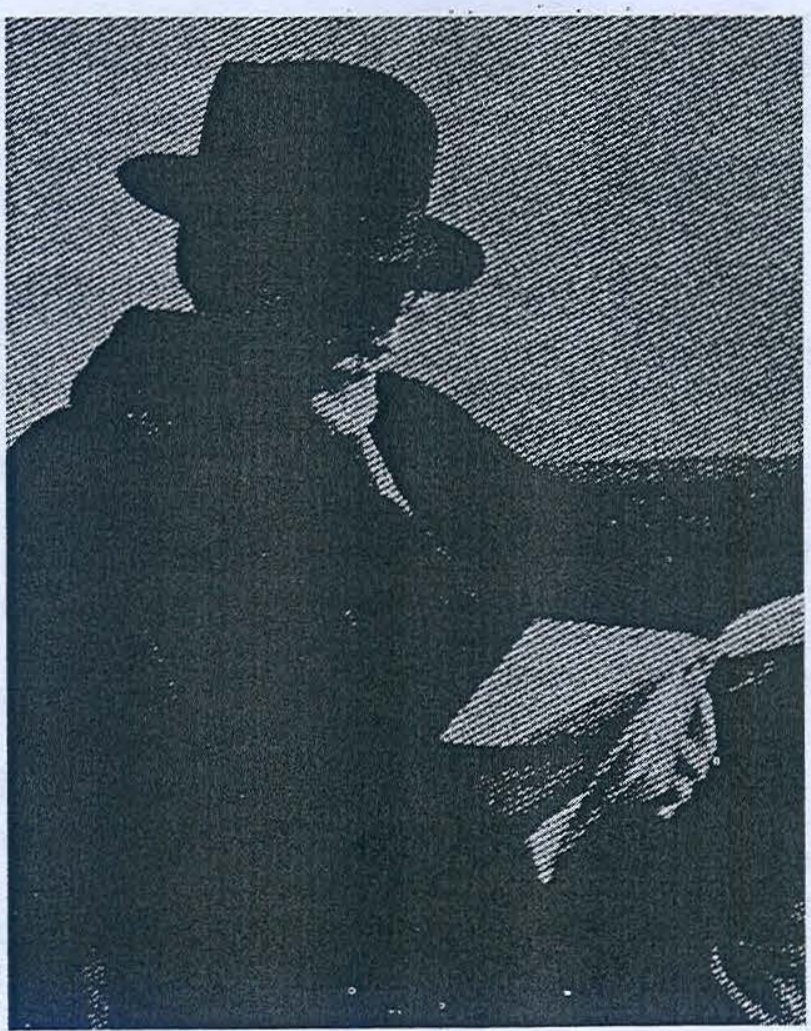

Picture 1: Zoltán Kodály (1882-1967) 


\section{The Kodály Method in Music Education}

Zoltán Kodály (1882-1967) was a composer, musicologist, and music educator. As a composer, he is best known for a suite from his opera "Hary Janos", for the "Peacock Variations", and for the "Psalmus Hungaricus". As a musicologist, he cooperated with Bela Bartok in collecting a large number of Hungarian folksongs. As a music educator, he established the guidelines on which a 'perfect' curriculum in music education has been built. $^{2}$ Joseph Labuta and Deborah Smith explained the Kodály method as follows:

Kodály and Bartok shared the vision of a musically literate Hungary, but it was Kodály's philosophy, principles, and goals that evolved into the Hungarian way of music education. This philosophy included six primary points: (1) Everyone who is capable of developing language literacy is capable of becoming musically literate; (2) singing is the best and most natural, practical, and effective means of acquiring musicianship; (3) to be most effective, music education must begin when children are very young; (4) children's "mother tongue" (children's native folksongs) should serve as the foundation of early instruction; (5) music teaching should use only repertoire of the highest quality; and (6) music should be a core subject in school curricula.

The pedagogy known as the Kodály method, or "the singing method," stemmed from these ideas and philosophy. The sequential nature of the curriculum is largely of Kodály's design, but the instructional techniques used to attain the curriculum's musical objectives were borrowed from a variety of sources. The method by which students learn to read and write music under this curriculum is called "relative sol-fa" and was derived from the tonic sol-fa system developed and used in England by John Curwen sometime after 1840. This sol-fa method uses the movable-rather than fixed-do system, and pitches are represented by their initial letter (do becomes $\mathrm{d}$, re becomes $\mathrm{r}$, and so on).

Regarding rhythmic notation, Kodály deviated from Curwen's system, using stems without note heads except for half notes and notes of longer duration. To these he added rhythm syllables derived from French pedagogue Emile Chev.. He also adopted Curwen's hand signals, used for each pitch of the scale. (see Picture 2)

\footnotetext{
${ }^{2}$ Landis and Carder (1972: 42).
} 


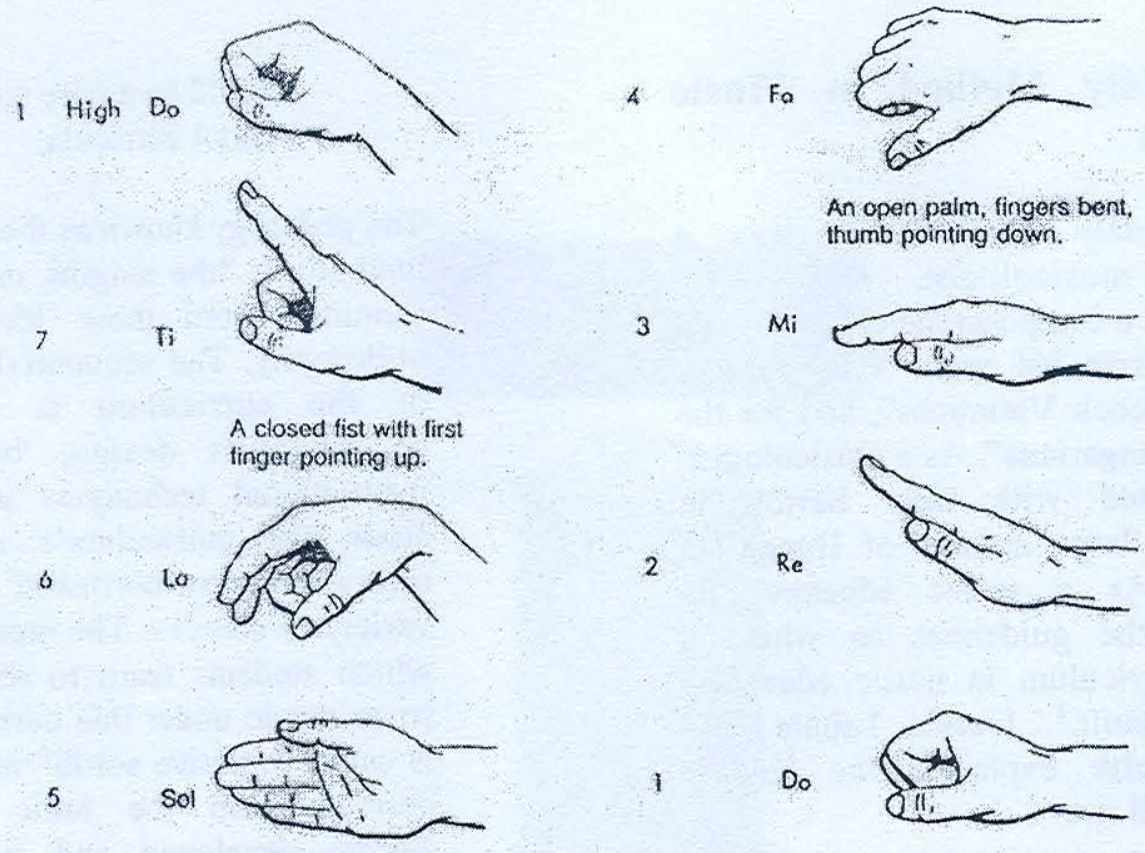

KODÁLY HAND SIGNS

\section{Picture 2: Hand Signs}

These signals were specifically designed to convey the tendencies of pitches as they are normally used in musical contexts.

In addition to these tools, Kodály's pedagogical approach uses a number of other materials, all designed to accommodate young children's musical, mental, and physical needs. Use of the pentatonic (five-tone) scale, iconic notation (using figures other than traditional music symbols to represent aspects of music), musical games, and staff placemats (sheets of paper or pieces of felt $8-1 / 2 \times 11$ inches or larger placed lengthwise, with five lines representing the staff drawn on them) with markers or circular math counters for notes are all based on Kodály's understanding

\footnotetext{
${ }^{3}$ Labuta and Smith (1997: 111-113).
} 
Robert Nye ${ }^{4}$, Don Collins ${ }^{5}$, and Patricia Campbell $^{6}$ reported that the Kodály method had influenced music education in the United States and in other countries in the latter part of the twentieth century.

\section{My Experiments with the Kodály Method}

Being certain that the Kodály method would work well with Thai students because of its "good quality at a cheap price", I attended Kodály workshops at the University of North Texas, was awarded a certificate, and started a Kodály program with first-grade students of the laboratory school of Kasetsart University in 1990. During that time, I went to Hungary to observe music pedagogy at the Kodály Institute. After six years of experimentation, I developed a music curriculum to teach Western music notation. My students achieved good competencies in sight reading music, in singing, and in playing the recorder. They could read music in five keys : C, F, G, D, and B flat. Former students learning music before the use of the Kodály method had been able to read only in the key of $\mathrm{C}$ and had not been able to sing as well as the students in the latter group.
This Kodály program won an award from Kasetsart University Research and Development Institute (KURDI) for the best research study in the field of Humanities in 1998.

Since Kodály urged the use of folksongs and game songs to teach music literacy, I would like to present here two Thai game songs which children love to play. They are "Mon Son Pha" and "Phong-phang". These two songs can be used to teach the eight others.

"Mon Son Pha" is a circle game which refers to the "Mon" people, a nation close to Thailand. In the past, Mon people migrated to Thailand and became Thai natives. Today, the Mon nation is almost extinct. The original song of "Mon Son Pha" is as follows:

\footnotetext{
${ }^{4}$ Nye, et al. (1992: 6).

${ }^{5}$ Collins (1993: 40).

${ }^{6}$ Campbell and Scott-Kassner (1995: 68).

${ }^{7}$ Narkwong, et al. 1997.
} 


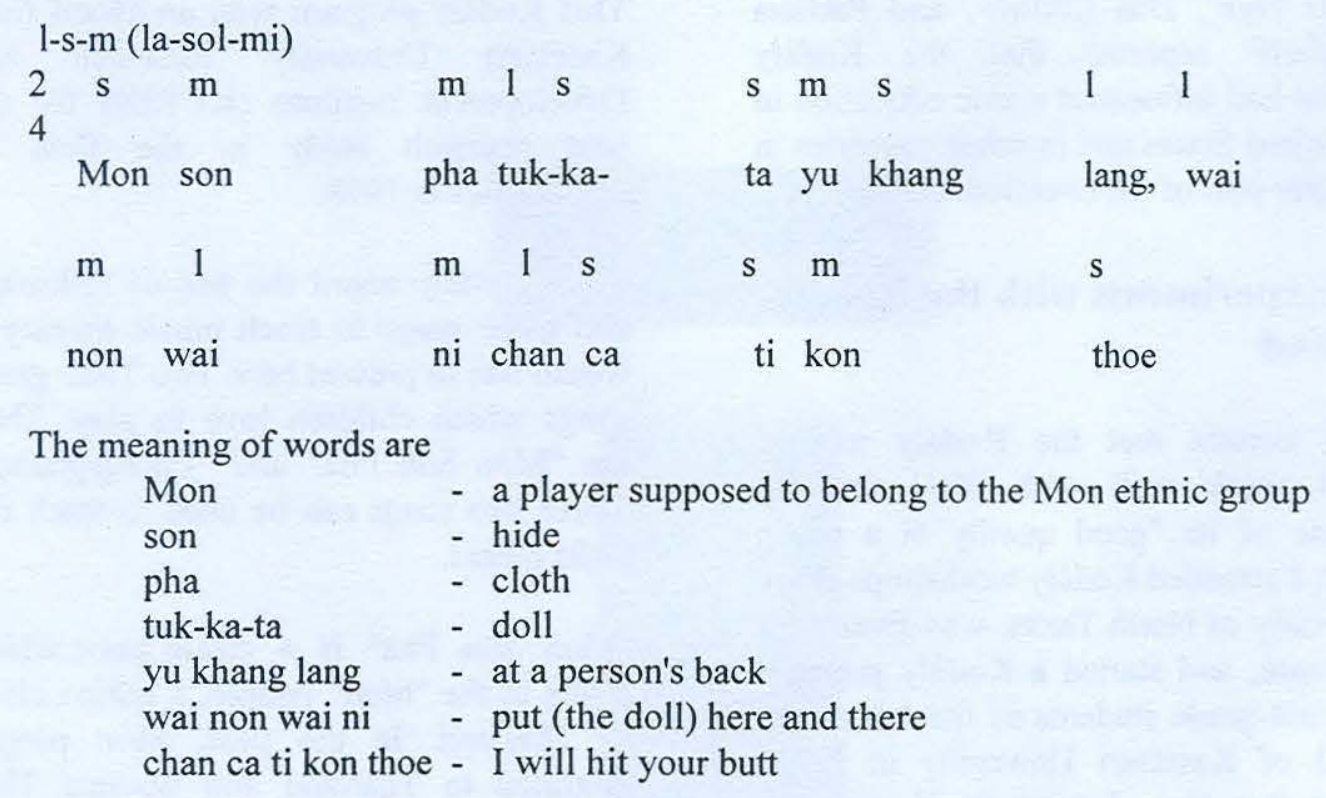

The meaning of words are

$\begin{array}{ll}\text { Mon } & \text { - a player supposed to belong to the Mon ethnic group } \\ \text { son } & \text { - hide } \\ \text { pha } & \text { - cloth } \\ \text { tuk-ka-ta } & \text { - doll } \\ \text { yu khang lang } & \text { - at a person's back } \\ \text { wai non wai ni } & \text { - put (the doll) here and there } \\ \text { chan ca ti kon thoe } & \text { - I will hit your butt }\end{array}$

The game starts with children sitting in a circle facing inwards. Everybody sings the song repeatedly while a "Mon" walks around outside of the circle. $\mathrm{He} /$ she hides a cloth doll behind his/her back. While he/she is walking, he/she drops the doll behind a child who is unaware. Pretending that he/she still holds the doll. The "Mon" tries to walk round and return to the rear of the child where he/she dropped the doll. The doll is then picked up and used to hit the sitting child's buttocks. That child must immediately run away around the circle and come back to his/her place. The "Mon" will run and try to hit the child's buttocks. After the child has returned to his place, the "Mon" will resume his/her role and play another round, trying to hide the doll somewhere else. But, if the child knows that a doll is dropped behind $\mathrm{him} / \mathrm{her}$, he/she will pick up the doll, chase the "Mon" and hit him/her with the doll. The "Mon" will run to replace the child in the circle and the child will take on the role of "Mon". 
I propose here an adapted tune in English.

1-s-m

\begin{tabular}{|c|c|c|c|c|c|c|c|}
\hline & $\mathrm{s} \quad \mathrm{m}$ & $\mathrm{m}$ & 1 & s & $\mathrm{s} \mathrm{m}$ & s & 1 \\
\hline & $\mathrm{Hi}$ - ding & cloth & cast & $\mathrm{a}$ & doll at & your & back. (If) You \\
\hline & 1 & $\mathrm{~m}$ & 1 & $\mathrm{~s}$ & $\mathrm{~s} \quad \mathrm{~m}$ & & $\mathrm{~s}$ \\
\hline & find & it & I & will & hit your & & butt. \\
\hline
\end{tabular}

"Phong-phang" is also a circle game. This game refers to "phong-phang" which is a sea fishtrap. When the sea runs dry, herons and wildcats sneak into the "phong-phang" to steal fish. The song is as follows:

$$
\begin{aligned}
& \text { 1-s-m }
\end{aligned}
$$

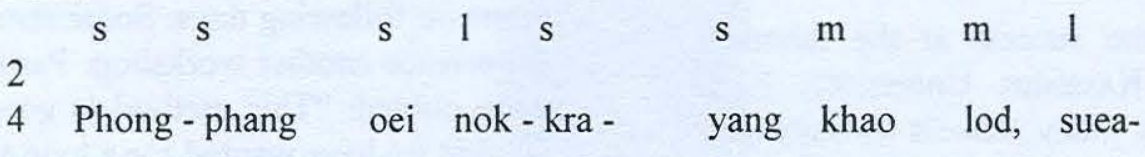

$$
\begin{aligned}
& \begin{array}{llllllll}
\mathrm{s} & \mathrm{s} & \mathrm{m} & \mathrm{m} & \mathrm{m} & \mathrm{s} & \mathrm{s}
\end{array} \\
& \text { pla ta- bod khao lod phong- phang. } \\
& \begin{array}{ll}
\text { phong-phang } & \text { - sea fishtrap } \\
\text { oei } & \text { - this word has no meaning, it is an interjection like oh! } \\
\text { nok-kra-yang } & \text { - heron } \\
\text { khao lod } & - \text { sneak in } \\
\text { suea-pla } & \text { - wildcat } \\
\text { ta-bod } & - \text { blind }
\end{array}
\end{aligned}
$$

This game starts with children standing in a circle facing inwards holding hands . (they are fish). They sing the song twice while the circle moves clockwise or counterclockwise. In the middle of the circle, stands a child blindfolded (as a blind wildcat). At the end of the song the circle of children chorus "live fish or dead fish?" The child in the circle then has two choices to answer. If he/she says, "live fish", then the child in the center can remove the blindfold and catch other children. The circle will scatter and the child who is caught then resumes the role of blind cat in the middle. If the child in the middle, on the other hand, says, "dead fish", then the circle must stand still with no sound uttered. The blind cat, still with blindfold, then walks slowly to someone in the circle (because he cannot see). $\mathrm{He}$ touches his friend's parts of body, then guesses who his friend is. If he says a 
correct name, the caught child resumes the role of a new blind cat. If he says a wrong name, he is still the blind cat. And the game starts over again.

I propose here an adapted tune in English.

$\begin{array}{lllllllllll}2 & \mathrm{~s} & \mathrm{~s} & \mathrm{~s} & \mathrm{~s} & \mathrm{l} & \mathrm{s} & \mathrm{s} & \mathrm{m} & \mathrm{m} & \mathrm{l} \\ 4 & \text { An } & \text { old } & \text { he- } & \text { ron } & \text { slips } & \text { in } & \mathrm{a} & \text { fish- } & \text { trap, al- } \\ & \mathrm{s} & \mathrm{s} & \mathrm{s} & \mathrm{m} & \mathrm{m} & \mathrm{m} & \mathrm{m} & \mathrm{s} & \mathrm{s} \\ & \text { so } & \text { a } & \text { blind } & \text { cat } & \text { slips } & \text { in the fish- } & \text { trap. }\end{array}$

\section{Kodály Method in Municipal Schools}

Following the success at the laboratory school of Kasetsart University, I was contacted by many schools in Bangkok to demonstrate the Kodály method to music teachers. In April, 1998, the TeachingLearning Development Center, Office of the National Education Commission awarded me the title of "Model Music Teacher" and assigned me the duty of training 19 music teachers from municipal schools in Bangkok. I introduced to them how to teach music concepts and how to set-up a curriculum in elementary school. They were satisfied and started using the Kodály method. In 1999, the Bangkok Metropolitan Administration, which controls all municipal schools in Bangkok, asked me to distribute the Kodály method again to 500 music teachers. I conducted three workshops; April 19-21, May 3-5, and May 10-12, 1999. Each workshop lasted three days (18 hours total). The workshop organizers reported to me that participants were so satisfied that there were more willing participants than could be enrolled. On the first day of workshop, some teachers appreciated the method so much that they persuaded their friends to come on following days. Some returned to experience another workshop. Participants were quoted: "This method is good. This is what we have wanted for a long time."

To my knowledge, there are presently two people who are taking leading roles in distributing the Kodály method in Thailand. As well as my own efforts, Dr. Narutt Suttachitt, a graduate from Indiana University, U.S.A. who was also awarded a Kodály certificate from the International Kodály Society in Hungary, is presently an associate professor at Chulalongkorn University in Bangkok. $\mathrm{He}$ teaches the Kodály method to university students, supervises a Kodály program in. Chulalongkorn University's lab school, and conducts workshops. In August, 1998, he invited Mark Williams from U.S.A. to give a workshop at Chulalongkorn University and a second workshop last year on March 29-April 2. Mark is an expert in the Kodály method who helps with Kodály workshops in South East Asia. 
The Possibility of Using the Kodály Method to Teach Music Literacy in Thailand

\section{Conclusion}

So far, the use of the Kodály method to teach music literacy in Thai schools is still at an experimental stage. According to my knowledge, the music teachers of municipal schools in Bangkok are currently interested in the Kodály method and are ready to try the method. If these teachers are successful in using the method, it may be distributed further to other groups of music teachers such as those in the public schools under control of the Ministry of Education and to private schools. This will take some years, because teachers need time to succeed in trying a new teaching method.

\section{References}

Campbell, Patricia Shehan and Carol ScottKassner. 1995. Music in Childhood: From Preschool through the Elementary Grades. New York: Schirmer Books.

Collins, Don L. 1993. Teaching Choral Music. New Jersey: Prentice-Hall, Inc.

Labuta, Joseph A. and Deborah A. Smith. 1997. Music Education: Historical Contexts and Perspectives. New Jersey: Prentice-Hall, Inc.

Landis, Beth and Polly Carder. 1972. The Eclectic Curriculum in American Music Education: Contributions of Dalcroze, Kodaly, and Orff. Washington: MENC.

Narkwong, Twatchai, et al. 1997. A Music Curriculum of Western Music Teaching Utilizing Kodály's and Orff's Methods in Elementary Education. Unpublished research study. Bangkok: Kasetsart University, Faculty of Humanities.

Nye, Robert E., Vernice Trousdale Nye, Gary M. Martin, and Mary Lou Rysselberghe. 1992. Music in the Elementary School. sixth edition. New Jersey: Prentice-Hall, Inc. 